\title{
Organizational Culture and Creative Processes Comparing German Theater Companies and Scientific Institutes
}

\section{Sabine Boerner, Diether Gebert}

An open organizational culture (for example, enhancement of individual autonomy) is needed in order to promote organizational creativity. But such openness can lead to problems with coordination that may jeopardize the organization's success. For example, an open organizational culture is accompanied by parallel processes of closure (promoting orientation, consensus, and trust) that reduce the negative secondary effects of openness (Gebert and others, 2004). It is thereby understood that the creative process in a theater company requires a greater effort at coordination than in scientific institutes. This is why cultural openness in a theater company comes with risk. Empirical results from interviews with 28 research institutes $(N=113)$ and 13 theater companies $(N=88)$ show that an open culture in theaters as well as in scientific institutes, is significantly connected to closed culture processes that serve as buffers. Furthermore, openness in a theater company in terms of risk prevention is developed significantly less than in scientific institutes. Also openness when the buffering closure is missing is not significantly connected to success in scientific institutes, and in theater companies there is even a significant negative connection. The need for buffering is thus especially meaningful for the results in a theater company.

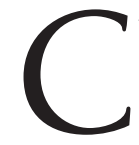

REATIVE PROCESSES in organizations are nourished by inspiration and the inventiveness of the organization's members. But they are also organized based on a division of labor. The result of a creative process therefore depends on the quality of coordinating the individual contributions. Trying to manage creative processes in organizations raises the paradox that the individual creativity of the organization's members needs to be encouraged by a maximum degree of freedom, but in the interest of coordinating individual contributions, these degrees of freedom need to be constrained. The larger the demand is for coordinating the respective creative processes, the more important this becomes. 


\begin{tabular}{c}
\hline On the \\
epistemological \\
dimension, \\
processes of \\
openness \\
encourage new \\
and creative \\
initiatives \\
\hline
\end{tabular}

The general problem of contradicting management requisitions in controlling creative processes in organizations was analyzed from the perspective of open versus closed organizational culture by Gebert and Boerner (1999). In their analyses of open and closed organizational cultures, Gebert and Boerner distinguish three dimensions. The anthropological dimension (voluntarism versus determinism) is the fundamental distinction between the thinking of an open culture and that of the closed culture. It is the question of whether societal reality is perceived primarily as the work of humans and, hence, as something alterable (the human being as subject, the voluntarist principle), or whether it is interpreted as an immutable result of the work of higher powers (such as providence or fate) over which humans have no influence (the human being as object, the determinist principle).

The social dimension (individualism versus collectivism) in open cultures highlights members' equality, heterogeneity of interests, and individualism. A closed organizational culture is characterized by inequality, homogeneity of interests, and collectivism.

Finally, there are differences on the epistemological dimension (tentativeness versus definitiveness). Within an open organizational culture, human knowledge is generally considered imperfect and thus preliminary. Insight is gained stepwise by using a trial-and-error method. In a closed culture, available knowledge is held to be error free and definitive.

With reference to Gebert and Boerner's model (1999), we first show that the encouragement of creative processes calls for open processes but at the same time requires closed processes to cushion the negative secondary effects that are caused by the openness. Second, we show that in the course of an increased need for coordination of the processes in theater companies, the degree of an open culture in the theater is lower and comes with special risk. We therefore focus on the diverse impact of open and closed processes for success in theater companies and scientific institutes. We then test our hypothesis in an empirical study in research institutes and theater companies.

\section{Balancing Open and Closed Organizational Cultures}

Creative achievements, defined through their novelty (Shalley, Gilson, and Blum, 2000), are supported by an open organizational culture. On the epistemological dimension, processes of openness encourage new and creative initiatives. If final truths are not alleged, new options can be realized, and reality appears as bound to change.

This is the motivational prerequisite for thinking about whether organizational reality is susceptible to change along the anthropological dimension. An open organizational culture, in which each individual considers herself or himself not an object but a subject, 
enhances the development of creative impulses. That is because everybody thinks he or she is able to change something (Gebert and others, 2003).

If equality and the assumption of heterogeneity of interests apply on the social level (the assumption of individualism in the open culture), then all members of the organization, not only experts, will be allowed to offer suggestions for change. This increases the potential for creative solutions. Furthermore, barriers to creativity stemming from group conformity are more likely to be overcome within an individualistic culture.

At the same time, however, an opening of an organizational culture is connected to unplanned negative secondary effects, which impair the creative processes, particularly coordination within organizations (Gebert, Boerner, and Lanwehr, 2003). A unidirectional opening of the organizational culture jeopardizes the aggregation of individual creative impulses, since inflationary and unfeasible claims for change are being formulated. Also, a pronounced heterogeneity of group members puts a burden on mutual communication and leads to dysfunctional effects (for example, conflicts). Finally, there is a danger of endless discussions (see Figure 1).

This is why processes of closure simultaneously occur in organizations. These processes improve the integration of the organization: orientation, consensus, and trust buffer the negative side effects of a unidirectional opening. Orientation, defined in terms of the clarity of the overall strategic course set by the organization, determines the direction and cognitive scope for potential creative impulses, thus setting cognitive limits on the process of developing creative

Figure 1. Positive and Negative Effects on the Generation and Coordination of Creative Ideas Resulting from an Open Organizational Culture

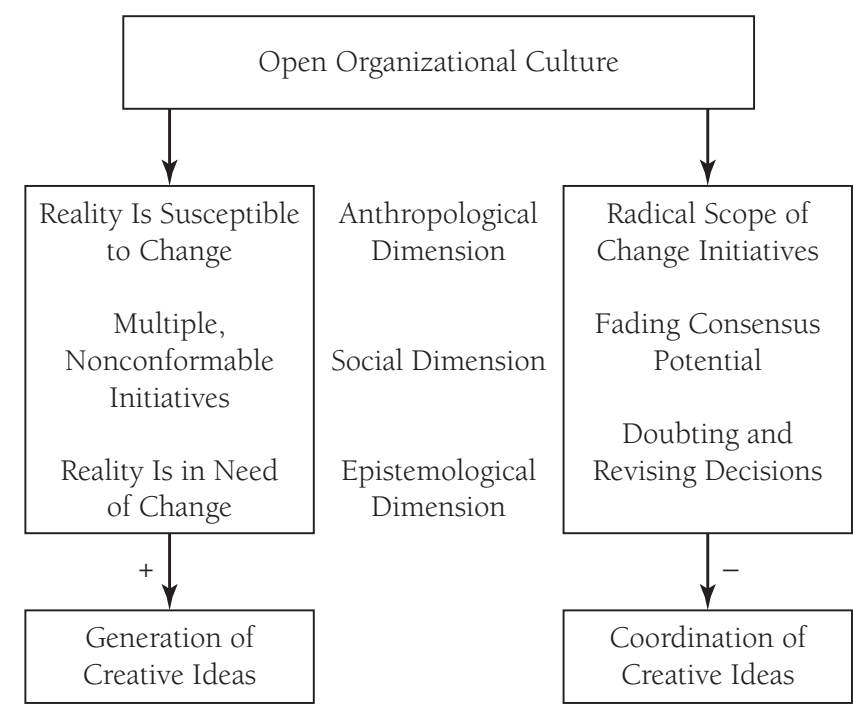




\begin{tabular}{c}
\hline The artistic \\
production \\
process in a \\
theater company \\
is characterized \\
by high \\
simultaneous task \\
interdependence \\
\hline
\end{tabular}

initiatives. Consensus, defined as the capacity to reach agreement within the organization on fundamental issues, obviates debates on principles when specific creative initiatives are to be modified in the course of coordination. We define trust as mutual willingness to accept vulnerability (even without contractual protection; Rippberger, 1998). Trust reflects the experience of mutual fairness and reliability (Rousseau, Sitkin, Burt, and Camerer, 1998), which reduces the likelihood of micropolitical intentions being mutually imputed, reducing endless doubt and revision of ideas when creative initiatives are under discussion. The buffering effect of integration (by orientation, consensus, and trust) has been empirically shown in for-profit organizations in different industries (Gebert, Boerner, and Lanwehr, 2003, 2004).

\section{The Balance Between Open and Closed Organizational Culture in Scientific Institutes and Theater Companies}

The artistic production process in a theater company is characterized by high simultaneous task interdependence (Saavedra and others, 1993). During a performance, the contributions of the artistic participants (for example, singers and musicians in an orchestra) must be generated simultaneously in order to create the impression of a unanimous interpretation (Boerner, 2002; Boerner and von Streit, forthcoming). As a result of simultaneous interdependence, the processes as such in the theater performance have to be coordinated.

A research project, by contrast, calls for simultaneous actions of its team members only in exceptional cases. As a rule, subtasks are defined and then processed by the participants in an independent way, at least temporarily. Therefore, sequential task interdependence prevails in scientific organizations (Saavedra, Earley, and Van Dyne, 1993). In research, predominantly partial results are being coordinated, which essentially arose from independent subprocesses.

Given this background, one can assume that although parallel integration is applied, the remaining dangers to coordination caused by openness will be higher in theater companies than in scientific organizations. The negative secondary effects of opening a theater company's organizational culture cannot be fully absorbed by parallel integration. Consequently, the degree of openness in the theater company will be limited from the outset for the purpose of prophylaxis. To sum up, the following differences with respect to the organizational culture of theater companies and scientific organizations are being assumed. They will be put to empirical testing in the following section.

Hypothesis 1. The phenomenon of balancing can be found in both theater companies and scientific institutes. There will be a positive relationship between an open and a closed culture. 
HYPOTHESIS 2. In scientific institutes, there will be a positive relationship between the openness of organizational culture and research quality, given parallel processes of closure through integration. In theater companies, the relationship between opening the organizational culture and the success of the organization (here, artistic quality) will be smaller than in the research context, despite parallel processes of closure through integration.

HYPOTHESIS 3. Theater companies will show a lower degree of cultural openness than scientific organizations do.

HYPOTHESIS 4. Without the buffer of integration (orientation, consensus, trust), the relationship between openness and organizational success will decrease in both types of organizations.

\section{Sample}

The sample for the theater companies resulted from a written survey completed by 88 employees from thirteen German public theater companies. Respondents came from both the artistic section (64 percent) and the technical section (36 percent) of the theater companies. The sample for the research sector consists of 113 employees from twentyeight German scientific organizations. Of those, about one-third (37 percent) work for institutes connected to universities and about two-thirds (63 percent) for institutes not connected to universities. Both types of organizations included in this study, theater companies and research institutes, are publicly owned and administered by government employees. Questionnaires were handed out personally, resulting in the return rate of 60 percent. (For more details describing the sample, see Boerner, 2002.)

\section{Measures}

For measuring the openness of an organizational culture, a previously validated questionnaire (Gebert, Boerner, and Matiaske, 1998) was adopted. Since the three dimensions of organizational culture are expected to form a pattern and are therefore highly intercorrelated, in this study a cumulative scale value was calculated across all items (see Table 1). Integration, defined through orientation, consensus, and trust, was measured by seven items, which were summed up to an overall integration value (see Table 2).

Evaluating the performance of organizations in the performing arts is extremely difficult (Boerner, 2004). To measure the artistic quality of a theater company, an instrument that had been of value in previous studies (Boerner, Krause, and Gebert, 2004; Boerner, 2002) was adopted. Those items of quality measurement (see Table 3) were summed up to an overall artistic quality value. 
Table 1. Measures for the Openness of an Organizational Culture

\begin{tabular}{ll}
\hline Dimension & Sample Items \\
\hline $\begin{array}{l}\text { Anthropological (voluntarism } \\
\text { versus determinism): } 16 \text { items }\end{array}$ & $\begin{array}{l}\text { The success of this organization is } \\
\text { attributed mainly to the ability to get things } \\
\text { moving and to bring about change actively. }\end{array}$ \\
$\begin{array}{l}\text { Social (individualism versus } \\
\text { collectivism): } 11 \text { items }\end{array}$ & $\begin{array}{l}\text { Within this organization, employees are } \\
\text { expected to make sacrifices in order to } \\
\text { achieve collective ideas and goals, thereby } \\
\text { putting back their personal goals once in a } \\
\text { while. (recoded) }\end{array}$ \\
$\begin{array}{l}\text { Epistemological (tentative- } \\
\text { ness versus definitiveness): } \\
9 \text { items }\end{array}$ & $\begin{array}{l}\text { Within this organization, there is a lot of } \\
\text { know-it-all and dogmatic behavior. } \\
\text { (recoded) }\end{array}$ \\
\hline
\end{tabular}

Note: Five-point scale $(5=$ yes; $1=$ no $)$ r reliability $($ Cronbach's alpha $)=.93$.

Table 2. Measures of Construct Integration: Orientation (O), Consensus (C), and Trust (T)

1. In your organization, nobody loses orientation; everybody feels confident how to think and act. (O)

2. The management in this organization always succeeds in providing a clear-cut basic orientation to employees. (O)

3. Even if a person is sometimes at a loss on details, the general direction of the task is clear. $(\mathrm{O})$

4. In your organization, everybody pulls together. Quarrels that would seriously harm unity are nonexistent. (C)

5. Even cumbersomely achieved agreements are being diluted again and again by grumblers and beraters. (C) (recoded)

6. In your organization, people can show their weaknesses without it being used against them. (T)

7. One may have serious doubts on the right proceeding in this organization, yet by no means may you express them. (T) (recoded)

Note: Five-point scale $(5=$ yes; $1=$ no); reliability $($ Cronbach's alpha $)=.78$.

\section{Table 3. Conceptualization of Artistic Quality in the Theater Company}

How do you personally judge the artistic quality of the performances in your theater company?

1. In terms of your personal quality standards/expectations

2. In terms of audience reaction

3. In terms of reaction by the press (critics)

4. In terms of reaction by the artistic director

5. ... compared to other theater companies

Note: Seven-point scale ( 1 = very low; 7 = very high); reliability (Cronbach's alpha) $=.77$. 
Table 4. Conceptualization of Research Quality

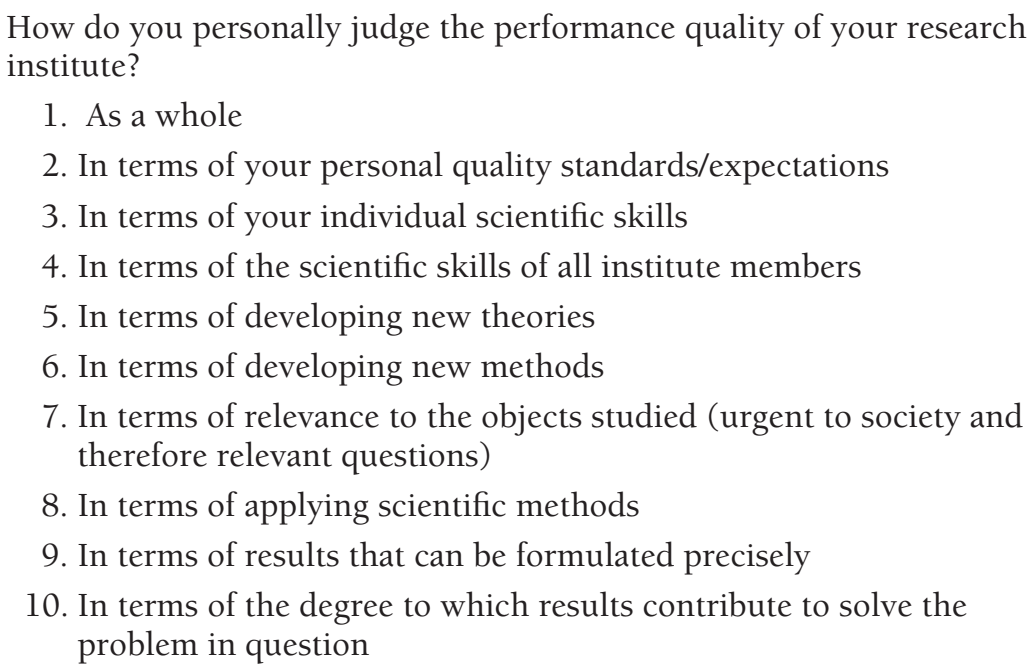

Note: Seven-point scale ( 1 = very low; 7 = very high); reliability (Cronbach's alpha) $=.92$.

Approaches to measure the quality of scientific organizations already exist; they remain, however, controversial (Bolsenkötter, 1986; Hüfner, 1991). This is why the study at hand predominantly adopts abstract rating scales on the recommendation of the Wissenschaftsrat, an advisory body on questions of science to the German government (Wissenschaftsrat, 1975). Those items are summed up to an overall research quality value (see Table 4).

\section{Results}

With openness increasing, processes of closure, namely orientation, consensus, and trust, advance in both scientific organizations and theater companies at the same time (see Table 5). Thus, the balance of parallel opening and closure of organizational culture assumed in hypothesis 1 is confirmed: the more the organizational culture opens up, the more parallel buffering processes of integration occur. This relationship between opening and closure partly explains the noticeable magnitude of the correlations (see Table 5). An additional explanation may be methodological: both constructs (opening and integration) were assessed by the same person. Thus the relationship might be overrated by percept-percept inflation (Crampton and Wagner, 1994).

In scientific organizations, a significant positive relationship is found between an open organizational culture and research quality $(r=.31 ; n=103 ; p<.01)$, while processes of closure persist at the same time (see Table 6). As hypothesis 2 assumes, the relationship between an open organizational culture and artistic quality in theater companies remains weaker than in scientific organizations,

\begin{tabular}{c} 
The more the \\
organizational \\
culture opens up, \\
the more parallel \\
buffering \\
processes of \\
integration occur \\
\hline
\end{tabular}


Table 5. Intercorrelations Between Processes of Opening and Processes of Closure by Integration in Theater Companies and Scientific Institutes

\begin{tabular}{llllll}
\hline & \multicolumn{2}{c}{ Theater Companies } & & \multicolumn{2}{c}{ Scientific Institutes } \\
\cline { 2 - 5 } & $\begin{array}{l}\text { Opening } \\
\text { Processes }\end{array}$ & Integration & & $\begin{array}{l}\text { Opening } \\
\text { Processes }\end{array}$ & Integration \\
\hline Opening & 1 & & Opening & 1 & \\
processes & $(88)$ & & processes & $(113)$ & \\
Integration & $.75^{* * *}$ & 1 & Integration & $.74 * * *$ & 1 \\
& $(54)$ & $(58)$ & & $(80)$ & $(95)$ \\
\hline
\end{tabular}

Note: ${ }^{* *} p<.001$. Number of cases are in parentheses. Fluctuations of sample size are due to missing values. Items concerning integration could be presented to only a fraction of the respondents in both samples.

Table 6. Intercorrelations Between Processes of Opening and Organizational Performance in Theater Companies and Scientific Institutes

\begin{tabular}{llllll}
\hline & \multicolumn{2}{c}{ Theater Companies } & & \multicolumn{2}{c}{ Scientific Institutes } \\
\cline { 2 - 3 } & $\begin{array}{l}\text { Opening } \\
\text { Processes }\end{array}$ & Integration & & $\begin{array}{l}\text { Opening } \\
\text { Processes }\end{array}$ & Integration \\
\hline Opening & 1 & & Opening & 1 & \\
processes & $(88)$ & & processes & $(113)$ & \\
Artistic & .20 & 1 & Research & $.31^{* *}$ & 1 \\
quality & n.s. & $(79)$ & quality & $(103)$ & $(103)$ \\
& $(71)$ & & & & \\
& & & & & \\
\end{tabular}

Note: ${ }^{*} p<.01$. Number of cases in parentheses. Fluctuations of the sample size are due to missing values.

despite parallel processes of a closed culture. In the theater companies' case, the amount of the correlation is lower than in the case of the research institutes and is no longer significant $(r=.20 ; n=71$; n.s.; see Table 6).

As Table 7 shows, the degree of openness of organizational culture is significantly lower in theater companies than in research organizations. As hypothesized (hypothesis 3), in terms of a preventive strategy, theater companies avoid too much openness. Accordingly, empirical studies show that leadership style in theater companies is more authoritarian than participative or delegative (Boerner, 2002; Boerner, Krause, and Gebert, 2004).

Finally, the buffer effect stemming from integration can be shown for both organization types (see hypothesis 4). Without parallel integration processes, the relationship between an open organizational culture and the corresponding organizational outcome (research 
Table 7. Differences in Degree of Openness Between Theater Companies and Scientific Institutes

\begin{tabular}{|c|c|c|c|c|c|c|}
\hline & \multicolumn{2}{|c|}{$\begin{array}{l}\text { Theater Companies } \\
\qquad(n=88)\end{array}$} & \multicolumn{2}{|c|}{$\begin{array}{l}\text { Scientific Institutes } \\
\quad(n=113)\end{array}$} & \multirow[b]{2}{*}{$t$} & \multirow[b]{2}{*}{ p } \\
\hline & Mean & $\begin{array}{l}\text { Standard } \\
\text { Error }\end{array}$ & Mean & $\begin{array}{l}\text { Standard } \\
\text { Error }\end{array}$ & & \\
\hline Openness & 112.33 & 2.49 & 124.00 & 2.05 & -3.64 & .000 \\
\hline
\end{tabular}

Note: Results of $t$-tests for independent samples. Fluctuations in sample size are due to missing values. High values $=$ high degree of openness.

quality and artistic quality, respectively) decreases considerably. This buffer effect becomes visible when the variable integration is controlled. If integration within scientific organizations is partialed out of the relationship between processes of opening and research quality, the relationship is no longer significant $(r=.09 ; n=54 ; n . s$.$) .$ The difference between this partial correlation and the correlation calculated above (see Table 6$)$ is significant $(t=1.83 ; p<.05)$. Thus, without the buffer of integration, the positive effects of open processes in scientific organizations will be neutralized by negative secondary effects.

In theater companies, however, without parallel closed processes of integration, the positive effects of open processes will not only be neutralized but tend to result in overcompensation. If integration is controlled for, the correlation between processes of opening and artistic quality will become negative $(r=-.29 ; n=43 ; p<.05)$. In other words, without parallel integration, processes of opening the organizational culture in theater companies will lead to dysfunctional effects on the artistic quality. The difference between this partial correlation and the bivariate correlation (see Table 6) is also significant $(t=2.04 ; p<.05)$.

\section{Discussion}

Looking at methodology, one must point to the constraints of the possible autocorrelative overestimation regarding the high correlation between the variables considered. Although different authors weight this problem differently, the validity can be diminished, and this must be seen critically (Fuller, Coleman, Patterson, and Stringer, 1996; Keller, 1992). Furthermore, the results of this study cannot be generalized to any particular scientific organization or theater company. Nevertheless, the partial analytical findings support the thesis that an open culture is aligned with risks not only in for-profit organizations (Gebert, Boerner, and Lanwehr, 2003, 2004) but in the particular public creative organizations studied in this investigation. A third methodological limitation of this 


\begin{tabular}{c} 
The idea that \\
theater \\
companies and \\
research \\
organizations \\
need an open \\
organizational \\
culture because \\
they produce \\
creative results is \\
not wrong, but it \\
is incomplete \\
\hline
\end{tabular}

The idea that need an open organizational culture because they produce creative results is not wrong, but it is incomplete: like organizations in the forprofit sector, theater companies and research organizations need parallel integration through orientation, consensus, and trust. Second, the idea that theater companies and research organizations, being creative organizations to the same degree, need a similar kind of balance of open and closed culture is wrong: due to the high demand for process coordination in a theater company, the degree of openness is smaller here than in research organizations.

A particular challenge for the management of both theater companies and research organizations is to provide integration through orientation, consensus, and trust without destroying the creative potential lying in ambiguity, dissent, and controversial discussions in their organizations.

SABINE BOERNER is a professor at the University of Konstanz, Germany. She holds the Chair of Management in the Department of Politics and Management.

DIETHER GEBERT is a professor at Berlin Technical University. He holds the Chair for Human Resource Management in the Faculty of Economics and Management.

\section{References}

Boerner, S. Führungsverhalten und Führungserfolg: Beitrag zu einer Theorie der Führung am Beispiel des Musiktheaters [Leadership behavior and leadership success: A contribution to a theory of leadership taking the example of opera companies]. Wiesbaden: Gabler, 2002. 
Boerner, S. "Artistic Quality in an Opera Company: Toward the Development of a Concept." Nonprofit Management and Leadership, 2004, 14 (4), 425-436.

Boerner, S., Krause, D. E., and Gebert, D. "Leadership and Cooperation in an Orchestra: An Empirical Study." Human Resource Development International, 2004, 7 (4), 465-479.

Boerner, S., and von Streit, C. "Transformational Leadership and Group Climate: Empirical Results from German Symphony Orchestras." Journal of Leadership and Organizational Studies, forthcoming.

Bolsenkötter, H. "Ansätze zur Erfassung und Beurteilung von Forschungsleistungen" [The evaluation of research performance]. In R. Fisch and H.-D. Daniel (eds.), Messung und Förderung von Forschungsleistungen. Konstanz, Germany: Universitätsverlag, 1986.

Crampton, S., and Wagner, J. "Percept-Percept Inflation in Microorganizational Research: An Investigation of Prevalence and Effect." Journal of Applied Psychology, 1994, 79 (1), 67-76.

Fuller, J. B., Coleman, E. P., Patterson, K. H., and Stringer, D. "A Quantitative Review of Research on Charismatic Leadership." Psychological Reports, 1996, 78, 271-287.

Gebert, D., and Boerner, S. "The Open and the Closed Corporation as Conflicting Forms of Organization." Journal of Applied Behavioral Science, 1999, 35 (3), 341-359.

Gebert, D., Boerner, S., and Lanwehr, R. "The Risks of Autonomy: Empirical Evidence for the Necessity of a Balance Management in Promoting Organizational Innovativeness." Creativity and Innovation Management, 2003, 12 (1), 41-49.

Gebert, D., Boerner, S., and Lanwehr, R. "The More Situation Control, the More Innovation? Putting the Linearity Theses to the Test." International Journal of Entrepreneurship and Innovation Management, 2004, 4 (1), 98-114.

Gebert, D., Boerner, S., and Matiaske, W. "Offenheit und Geschlossenheit in Organisationen: Zur Validierung eines Messinstruments" [Openness and closedness in organizations: On the validation of an instrument for measurement]. Zeitschrift für Arbeits- und Organisationspsychologie, 1998, 42 (1), 15-26.

Hüfner, K. "Inter- und Intra-universitäre Kennzahlensysteme zwischen Anspruch und Wirklichkeit" [Performance indicators in universities between aspiration and reality]. In C. Helberger (ed.), Ökonomie der Hochschule II. Berlin: Duncker \& Humblot, 1991.

Keller, R. T. "Transformational Leadership and the Performance of Research and Development Project Groups." Journal of Management, 1992, 8(3), 489-501.

Rippberger, T. Ökonomik des Vertrauens [Economics of trust]. Tübingen, Germany: Mohr-Siebek, 1998.

Rousseau, D., Sitkin, S. B., Burt, R. S., and Camerer, C. "Not So Different After All: A Cross-Discipline View of Trust." Academy of Management Review, 1998, 23(3), 393-404. 
Saavedra, R., Earley, P. C., and Van Dyne, L. "Complex Interdependence in Task-Performing Groups." Journal of Applied Behavioral Psychology, 1993, 78 (1), 61-72.

Shalley, C., Gilson, L. L., and Blum, T. C. "Matching Creativity Requirements and the Work Environment: Effects on Satisfaction and Intentions to Leave." Academy of Management Journal, 2000, 43, 215-223.

Wissenschaftsrat (ed.). Empfehlungen zur Organisation, Planung und Förderung der Forschung [Recommendations to the organization, planning, and enhancement of research]. Bonn, Germany: Wissenschaftsrat, 1975. 